Int. J. Dev. Biol. 58: 829-839 (2014)

doi: $10.1387 / \mathrm{ijdb} .1403251 \mathrm{a}$

\title{
Transition from embryonic to adult epidermis in reptiles occurs by the production of corneous beta-proteins
}

\author{
LORENZO ALIBARDI* \\ Comparative Histolab and Dipartimento Bigea, University of Bologna, Italy
}

\begin{abstract}
The adaptation of the epidermis in amniote vertebrates to life on land took place by a drastic change from an embryonic epidermis made of two-four periderm layers to a terrestrialproof epidermis. This transition occurred by the increase in types and number of specialized corneous proteins coded by genes of the Epidermal Differentiation Complex. The prevalent types of corneous proteins produced in the reptilian epidermis contain a beta-sheet region of high amino acid homology which allows their polymerization into a meshwork of filaments forming the hard corneous material of scales and claws. The present immunogold ultrastructural study shows that this transition occurs with the synthesis of glycine-rich corneous beta-proteins (formerly indicated as beta-keratins) that are added to the initial framework of acidic intermediate filaments produced in the embryonic epidermis of lizards, snake, alligator and turtle. These corneous beta-proteins are accumulated in the transitional and definitive layers of reptilian epidermis formed underneath the transitory two-four layered embryonic epidermis. In the more specialized reptiles capable of shedding the epidermis as a single unit, such as lizards and snakes, special glycine-cysteine rich beta-proteins are initially produced in a single layer immediately formed beneath the embryonic epidermis, the oberhautchen. The latter layer allows the in ovo shedding of the embryonic epidermis in preparation for hatching, and in the following shedding cycles of the adult epidermis. The production of specialized corneous-specific beta-proteins in addition to intermediate filament keratins was probably an essential addition for terrestrial life during the evolution of reptiles into different lineages, including birds. The increase of glycine and cysteine in epidermal proteins enhanced the hydrophobicity, insolubility and mechanical strength of the stratum corneum in these amniotes.
\end{abstract}

KEY WORDS: reptiles, embryos, acidic keratins, corneous beta-proteins, immunocytochemistry

During the adaptation to land, vertebrates evolved a protective system against desiccation, mechanical insult, sunlight, and also a microbe barrier (Matoltsy, 1987; Elias and Choi, 2005). The stratified epidermis of pisciform vertebrates before land colonization in the Upper Devonian Period likely comprised keratinocytes capable to synthesize mainly simple keratins for cytoskeletal restrain from the stress imposed on their epithelial integrity and antimicrobial molecules capable to arrest microbes and other parasites (Alibardi, $2003,2008)$. With the emergence from water, the epidermis of amphibious forms in the Carboniferous Period was faced with further challenges mainly derived from sun radiations, rapid desiccation, and mechanical damage during movements on a dry substrate. The adaptation of amphibians to the new ecological niches of the terrestrial environment was in part made possible by the evolution of a number of new proteins that gradually transformed the process of keratinization, where keratins were by far the main components, into the process of cornification, in which other proteins became associated to keratins or to the plasma membrane of the superficial keratinocytes, turning them into corneocytes (Alibardi, 2006; Eckhart et al., 2013).

The evolution from the mono-bilayered stratum corneum in amphibian epidermis into a multilayered stratum corneum in the epidermis of basic amniotes in the Upper Carboniferous Period was probably made possible by the evolution of other corneous proteins in addition to hydrophobic type II keratins rich in glycine sequences (Klinge et al., 1987; Steinert and Freedberg, 1991). Genomic studies have suggested that these specialized corneous proteins are clustered in single loci, and their sequence and homology strongly suggest that all these genes are likely derived from the

Abbreviations used in this paper: EDC, epidermal differentiation complex. *Address correspondence to: Lorenzo Alibardi. Dipartimento di Biologia, Geologia e Scienze Ambientali, via Selmi 3, University of Bologna, 40126, Bologna, Italy.
Tel +39 051 204257. Fax +39 051 2094286. E-mail: Iorenzo.alibardi@ @unibo.it

Accepted: 16 December 2014

ISSN: Online 1696-3547, Print 0214-6282 

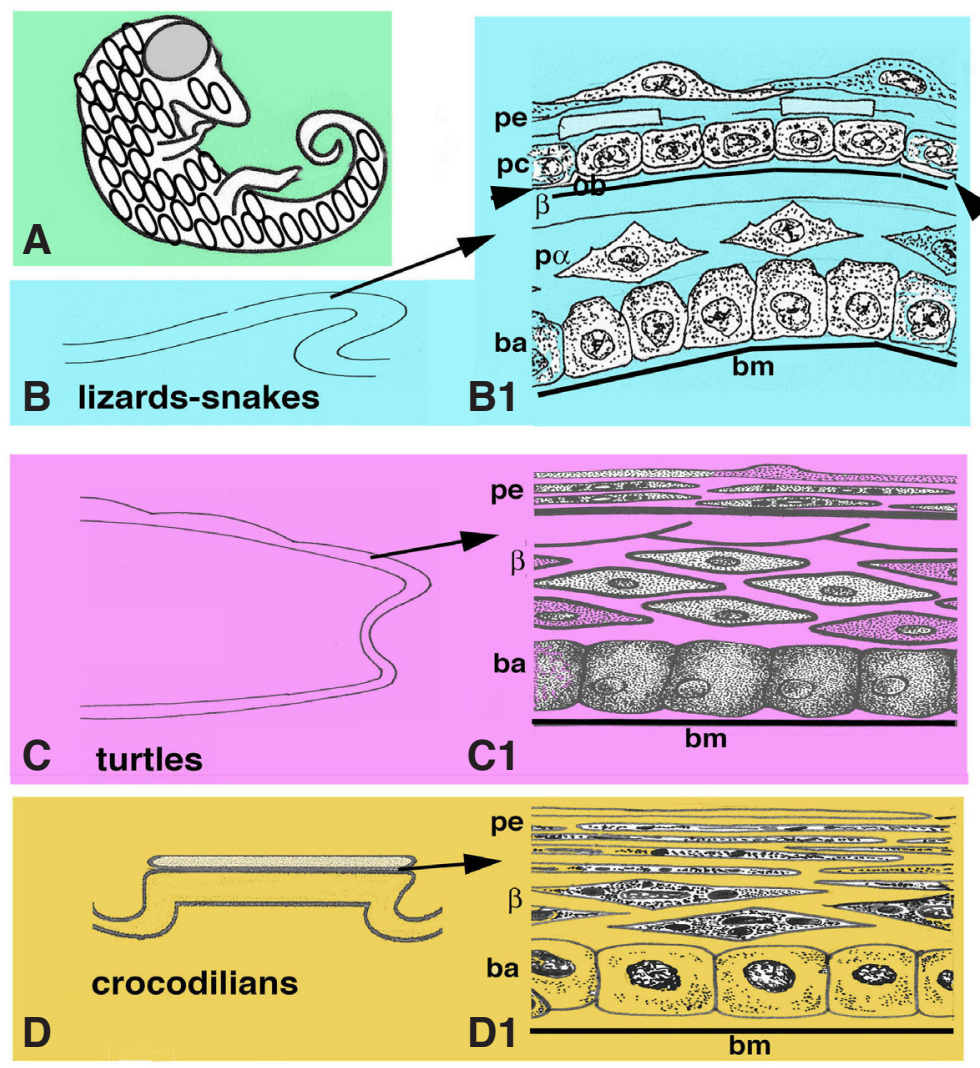

duplication and mutation from a single, ancestrale gene (Mischke et al., 1996). Particularly in amniotes with known genomes such as human, chick, zebrafinch and the green anole lizard, over 50 proteins have been detected in a locus indicated as Epidermal Differentiation Complex (EDC), including those mostly involved in the formation of the stratum corneum of the epidermis such as filaggrin, involucrin and loricrin, or trichohyalin in the IRS of hairs (Mischke et al., 1996; Kalinin et al., 2002; Vanhoutteghem et al., 2008; Mlitz et al., 2014; Strasser et al., 2014).

The epidermis derives from the differentiation of the ectoderm in the embryo that gives rise to the periderm and to a basal layer from which the definitive epidermis is later originated (Maderson,
Fig. 1. Schematic drawing showing the epidermal stratification that takes place in developing scales of reptilian embryos (A). The initial embryonic epidermis generally consist of 2 layers of peridermal cells. (B) In lizards and snakes, beneath the inner periderm or a third layer equivalent to the clear layer, an oberhautchen layer is formed together the shedding line (indicated by arrowheads). Fusiform beta-cells accumulate underneath. In turtles (C), beneath 2 layers of periderm and 3-4 layers of transitional cells (in the carapace epidermis), beta-cells accumulate but no specific shedding layer is formed. Also in crocodilians (D), beneath two periderm layers, betakeratinocytes are accumulated underneath. Abbreviations: ba, basal layer; bm, basement membrane; $\beta$, beta-cells laccumulating hard corneous material); ob, oberhautchen layer; $p \alpha$, pre-alpha layer; $p c$, pre-clear layer; pe, periderm.

1985; Byrne et al., 2003; Koster and Roop, 2004). The formation of the adult, definitive epidermal layers in amniotes, after the periderm has ceased its function of exchange epithelium with the amniotic fluid, occurs through changes that produce an epidermis adapted to the terrestrial environment (Maderson, 1972; Dhouailly and Maderson, 1984; Alibardi, 2003; Sawyer and Knapp, 2003). These changes involve the formation of an efficient stratum corneum against water-loss, mechanical insult, and microbial invasion (Elias and Choi, 2005).

These fundamental needs have been solved producing a number of specialized, non-keratin proteins of different composition and molecular structure, in the two extant lineages of amniotes, sauropsids (reptiles and birds) and mammals. In the adult epidermis these proteins, which genes are generally clustered in a specific chromosome locus indicated as Epidermal Differentiation Complex (EDC, see Vanhoutteghem et al., 2008), associate to intermediate filament keratins. Keratin genes are instead located in a different locus, and their fibrous proteins form the meshwork for the deposition of corneous proteins, a process that gives rise to the mature corneous material of the epidermis (Hardmann et al., 1998; Kalinin et al., 2002). This process may in part initiates in the embryo and determines the replacement of the embryonic epidermis, a term that indicates the temporary periderm layers destined to be shed before or at hatching (Sawyer et al., 2000, 2003; Alibardi, 2003, 2008), with a definitive epidermis that possesses efficient barrier properties against the harsh terrestrial

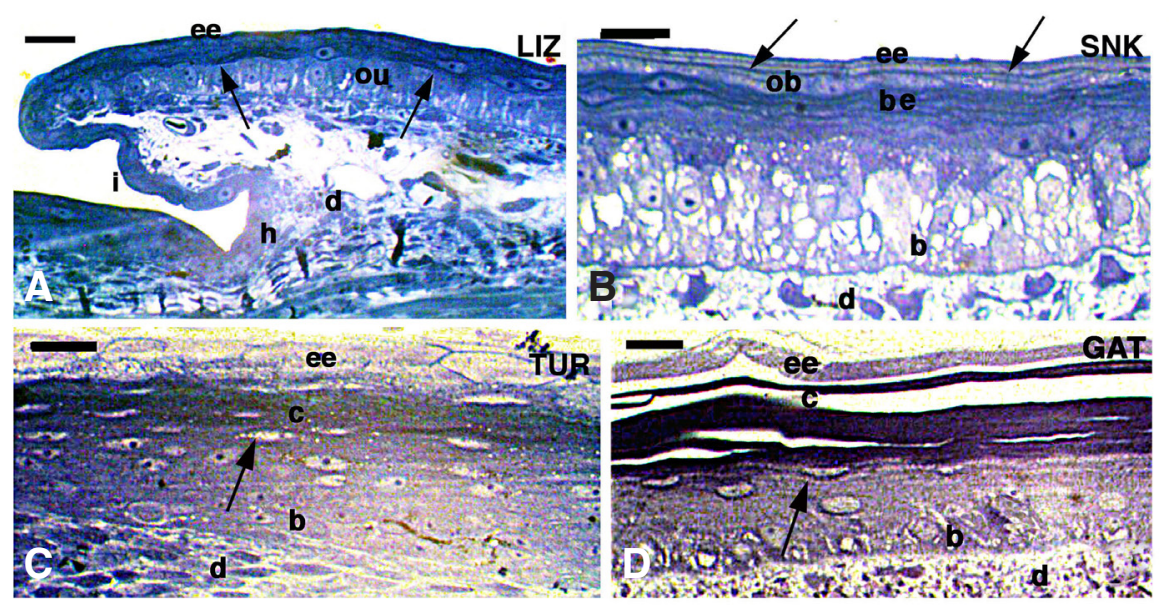

Fig. 2. Histology of the epidermis in lizard embryo ( $P$. muralis, LIZ) at stage $33(\mathrm{~A})$, snake (L. fuscus, SNK) at stage 36 (B), turtle (T. hermanni, TUR) at stage 24 (C), and alligator (A. missippippiensis, GAT) at stage 27 (D). Scale bars in all figures represent $10 \mu \mathrm{m}$. (A) ventral overlapped scales with superficial embryonic epidermis under which the first layer of fusiform betacells are seen (arrows). (B) detail of lateral trunk scale showing the forming dense shedding line (arrows) present beneath the external thin layers of embryonic epidermis. (C) pale polygonal cells of the embryonic epidermis of the carapace under which flat and darker corneous cells of the forming corneous layer are accumulating (arrow). (D) fusiform keratinocytes (arrow) accumulating in a dense corneous layer forming underneath the pale embryonic epidermis in a ventral scale. Abbreviations: b, basal layer; be, beta-layer (forming); c, corneous layer (made by beta-keratinocytes); d, dermis; ee, embryonic epidermis (periderm layers); h, inter-scale hinge region; i, inner (ventral) scale surface; ob, oberhautchen layer; ou, outer (dorsal) scale surface. 
conditions.

Previous studies have shown that the definitive epidermis in reptiles is made of alpha-keratins and corneous beta-proteins, formerly termed beta-keratins (Carver and Sawyer, 1987; Sawyer et al., 2000; Alibardi and Toni, 2006; Toni et al., 2007; Alibardi et al., 2009; Chang et al., 2009). Both molecular biology and biochemical studies have indicated that corneous beta-proteins are initially basic proteins but that during keratinocyte differentiation part of these proteins become acidic following post-translational processes such as phosphorylation, degradation (Toni et al., 2007), or even glycosylation (Staudt etal., 2012). Similar modifications may occur since the initial transition from the embryonic epidermis to the definitive, adult epidermis, but no information is available for reptiles.

The embryonic epidermis in sauropsids consists in 2 periderm layers and 1-6 transitional layers produced in a generalized skin or in specialized regions of the body (ramphoteca and claws), before the definitive keratinocytes of the adult epidermis are formed (Fig. 1). This temporary epidermis is characterized from the presence of embryonic organelles indicated as reticulate bodies or periderm granules (in birds) and of a soft form of keratinization (Akiyama et al., 1999; Alibardi, 2003, 2008; Sawyer and Knapp, 2003). These organelles are made by a meshwork of 25-50 nm thick coarse filaments that form irregular (reticulate bodies) or spherical (periderm granules) organelles, especially developed in the second or inner periderm layer. The specific role of these granules remains elusive, as they could be involved in the keratinization of the peridermis, in its breakage or simply represent the accumulation of waste proteins (Kuraitis and Bowers, 1978; Alibardi, 2003, 2008).

A recent study has shown that corneous beta-proteins rich in glycine are the main component of the corneous layer in adult turtles and crocodilians and of the resistant beta-layer in lepidosaurians (Alibardi, 2013b). Although the main cytological aspects of the transition between embryonic and definitive epidermis are known, it remains to be shown whether the initial adult layers accumulated beta-proteins rich in glycine like those of adult epidermis. The present study aims to detect whether glycine-rich or glycine-cysteine-rich beta-proteins are immediately accumulated in sub-periderm layers of reptiles in preparation to hatching. The observations complete previous studies made on adult normal and regenerating epidermis of reptiles and further sustain that the process of cornification in reptilian epidermis is due to the deposition of corneous beta-proteins on the tonofilaments generated in suprabasal cells.

\section{Results}

\section{Histology}

In the selected embryonic skin of the different reptilian species, the external embryonic epidermis of the outer (dorsal) scale surface appeared with a different thickness according to the species analyzed. In lizard at stage 38 (embryos with scaled and pigmented skin) a thin paler layer (1-2 $\mu \mathrm{m}$ thickness) was located above the initial but still forming beta-layer, made of one-two layers of spindle-shaped beta-cells (Fig. 2A). In the snake at stage 36 (embryo with a scaled and pigmented skin), the paler embryonic layers were located above a dense and continuous line indicating the formation of the oberhautchen layer, formed above two layers of spindle-shaped beta-cells (Fig. 2B).

In the turtle at stage 23 (embryos showing scutes in the shell with the beginning of pigmentation), the epidermis of the shell comprised a basal, suprabasal and one layer of spindle-shaped beta-cells formed above a basal layer. At stage 24 (scutes well pigmented), the epidermis was formed by 2 layers of large and pale cells present above 3-5 layers of flat and differentiating spindle-shaped beta-cells resting upon a basal layer (Fig. 2C). In ventral scales of alligator epidermis at stage 28 (well pigmented and completely scaled embryo close to hatching), the embryonic epidermis comprised a two-layered embryonic and pale layer located above a multilayered but compact corneous layer, followed by 2-3 layers of spindle-shaped, pre-corneous cells localized on top of the basal layer (Fig. 2D).

\section{Immunofluorescence}

The immunostaining obtained after application of pre-core box antibodies to sections of the skin in different species at the stages indicated above showed that the immunofluorescence was only

Fig. 3. Rhodamine immuno-fluorescence after application of the pre-core box antibody is present only in beta-corneocytes generated underneath the embryonic epidermis. Scale bars indicate $10 \mu \mathrm{m}$ in all figures. (A) lizard limb scale (LIZ) at stage 36 in P. muralis. (B) cross-sectioned ventral scale at stage 37 in A. lineatopus showing the intensely labeled beta-layer (arrowhead). (C) three narrow and overlapped tail scales (arrowheads on the beta-layer) of the lizard L. guichenoti at stage 37. (D) trunk scale of the snake L. fuscus (SNK) at stage 36. (E) thick shell epidermis of T. hermanni (TUR) at hatching, showing numerous layers of spindle-shaped beta-cells underneath the
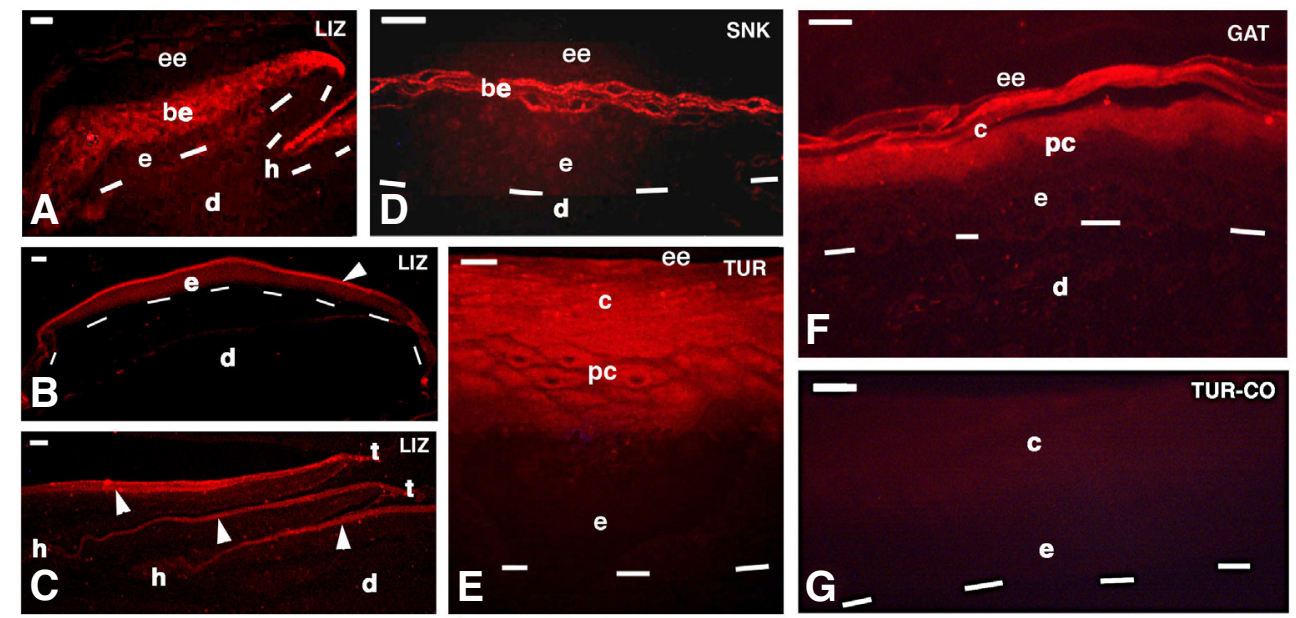

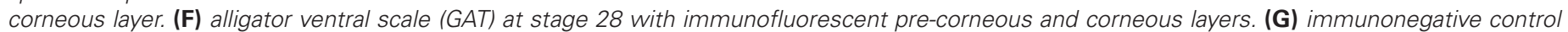

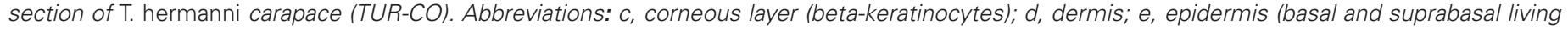

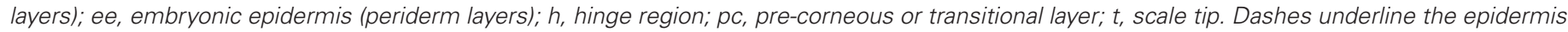




\section{L. Alibardi}
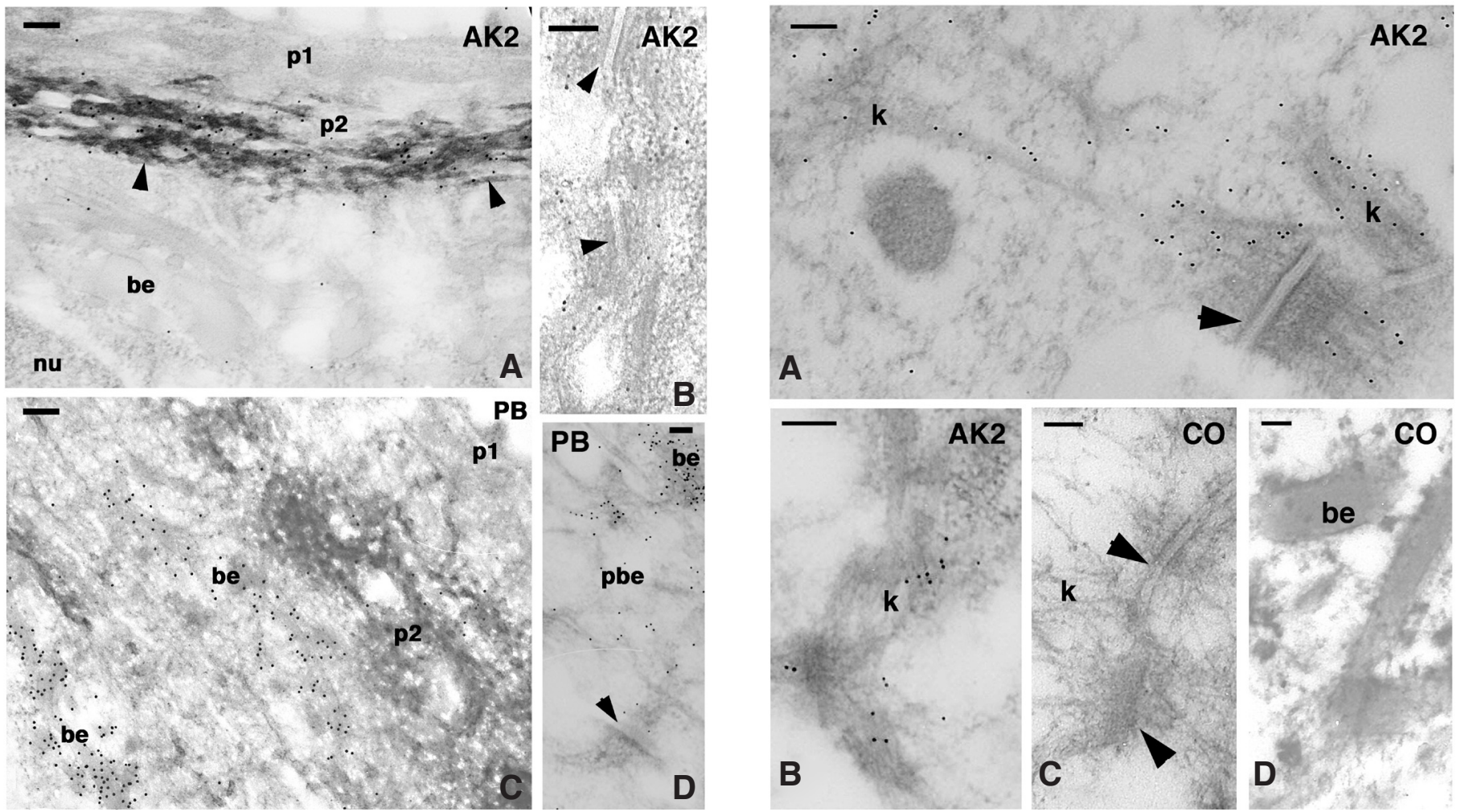

Fig. 4 (Left). Ultrastructural immunogold details of the epidermis of $\boldsymbol{P}$ muralis at stage 36. (A) diffuse immunolabeling for AK2 (alpha-keratin) mainly over reticulate bodies (arrowhead) of the inner periderm. Bar, $100 \mathrm{~nm}$. (B) AK2 diffuse labeling in tonofilaments converging to desmosomes (arrowheads) in suprabasal cells. Bar, $100 \mathrm{~nm}$. (C) Pre-core box (PB) immunolabeled corneous beta-packets formed in the first layer beneath the periderm. Bar, $100 \mathrm{~nm}$. (D) unlabeled tonofilaments and desmosomes (arrowhead) in suprabasal cell confining with a differentiating beta-cell where immunolabeled beta-packets are present. Bar, $100 \mathrm{~nm}$. Abbreviations: be, beta-packets (corneous mass); nu, nucleus; p1, outer periderm; p2, inner periderm; pbe, pre-beta cell (early differentiating beta-cell).

Fig. 5 (Right). Immunogold labeling for AK2-positive alpha-keratins (A,B) and controls (C,D) in suprabasal keratinocytes of $P$. muralis embryos. (A) Keratin bundles (k), including those joined to desmosomes (arrowhead), showing labeling. Bar, $100 \mathrm{~nm}$. (B) Detail of immunolabeled tonofilament (k) in basal keratinocyte. Bar, $100 \mathrm{~nm}$. (C) Unlabeled keratin filaments (k) and desmosomes (arrowheads) in a control (CO). Bar, 100 nm. (D) Unlabeled control (CO) in beta-bundles (be) of a differentiating beta-cell. Bar, $100 \mathrm{~nm}$.

localized below the embryonic epidermis, in the corneous and in the underlying differentiating and spindle-shaped, pre-corneous cells (Fig. $3 \mathrm{~A}-\mathrm{F}$ ). Immunofluorescence localization showed that the labeling was present over most cytoplasm of beta-cells except in the central region where the nucleus was located (Fig. $3 \mathrm{D}, \mathrm{E}$ ).

In lizard and snake scales the forming beta-layer, made of 2-3 layers of spindle-shaped cells, appeared fluorescent along the entire outer surface (dorsal) of embryonic scales (Fig. 3 A-D). In turtle at hatching numerous spindle-shaped beta-cells filled with immunofluorescent material were seen underneath a more compact corneous layer (Fig. 3E). In alligator scale an intense fluorescence was observed in the compact corneous layer and in differentiating and pre-corneous cells forming underneath (Fig. 3F). In controls, no immunofluorescence was seen (Fig. 3G).

\section{Ultrastructural immunocytochemistry for lizard epidermis}

The specificity of the 5 antibodies here utilized (AK2 for alphakeratins, HgGC10 for lizard, and PreCBs for crocodilians, turtles and lepidosaurians) was previously checked by pre-absorption with the specific antigens, western blotting and immunocytochemistry, and showed that they were only reactive for their specific reptilian group (Alibardi, 2013a). Therefore the antibody against the turtle epitope did not recognize both the crocodilian and the lepidosaurian epidermis and vice versa. The AE3 antibody for type II mammalian alpha-keratins previously showed to label lizard tonofilaments (Alibardi, 2003). The G28 antibody is a general antibody against beta-proteins (beta-keratins) from the chick and alligator (Sawyer et al., 2000).

The study on the ultrastructural details of the embryonic skin allowed the analysis of the precise localization of beta-proteins (pre-core-box antibodies, and the gly-cys-rich snake antibody) and of acidic alpha-keratins (AK2 antibody) in embryonic and definitive epidermis of the embryos. Previous ultrastructural studies indicated that beneath a bi-layered periderm containing reticulate bodies, the next layers are equivalent to the clear and oberhautchen layer in lizards and snakes, or to alpha- or beta-cells in crocodilians and turtles (Fig. 1 A-B1).

In the lizard $P$. muralis, a diffuse labeling for the AK2 antibody was seen in the embryonic layers, outer and inner periderm, but was more intense in the reticulate bodies present in the inner periderm (Fig. 4A). However the coarse filaments forming reticulate bodies appeared only marginally labeled while gold particles decorated 
their amorphous matrix. Little labeling was seen on tonofilaments converging to desmosomes linking periderm and subperidermal cells (Fig. 4B).

The pre-core box antibody instead labeled only the beta-cell layers underlying the embryonic epidermis, especially the pale beta-corneous packets or bundles of amorphous corneous material accumulating in these cells (Fig. 4C). This labeling suddenly disappeared in underlying cells, specifically in the transition between the last cell of the beta-layer and the first suprabasal cell not yet under differentiation (Fig. 4D). Conversely, in the differentiating pre-betacells and in suprabasal cells, a labeling of tonofilaments for the AK2 antibody was present, including keratin bundles converging to the desmosomes joining these cells (Fig. 5 A,B). In controls, both alpha-cells and beta-cells appeared unlabeled (Fig. 5 C,D).

In the lizard $A$. lineatopus, the first layer formed underneath the embryonic epidermis, characterized by the presence of pointed spines and termed oberhautchen, showed sparse immunolabeling for the HgGC10-antibody (Fig. 6 A,B). This epitope identifies a glycine-cysteine rich beta-protein present in this lizard, indicating that the latter protein begins to be deposited over alpha-keratins in the first layer formed beneath the periderm.

\section{Ultrastructural immunocytochemistry for snake epidermis}

The immunolabeling of the embryonic epidermis of $L$. fuscus, using the antibody Sn-cys-1 against a snake cysteine-rich-beta protein, produced a very specific labeling only in the first layer located underneath the two embryonic layers, which represents the first oberhautchen layer of snake epidermis (Figs. $6 \mathrm{C}-\mathrm{D}, 7 \mathrm{~A}$ ). This layer showed a marked 30-40 mn thick irregular or slanted line that separated the layer from the external two periderm layers (arrows in Figs. $6 \mathrm{C}, 7 \mathrm{~A}$ ). The large gold-silver intensified particles were located over the beta-corneous packets or bundles accumulated in this single cell-layer while did not localize over the dense limiting line of the oberhautchen. The labeling with this antibody uniquely extended to the thin oberhautchen layer present on the inner (ventral) scale surface of the embryonic scales (Fig. 6D). The differentiating beta-cells still in course of accumulation of betacorneous packets, and located undermeath the oberhautchen cells,

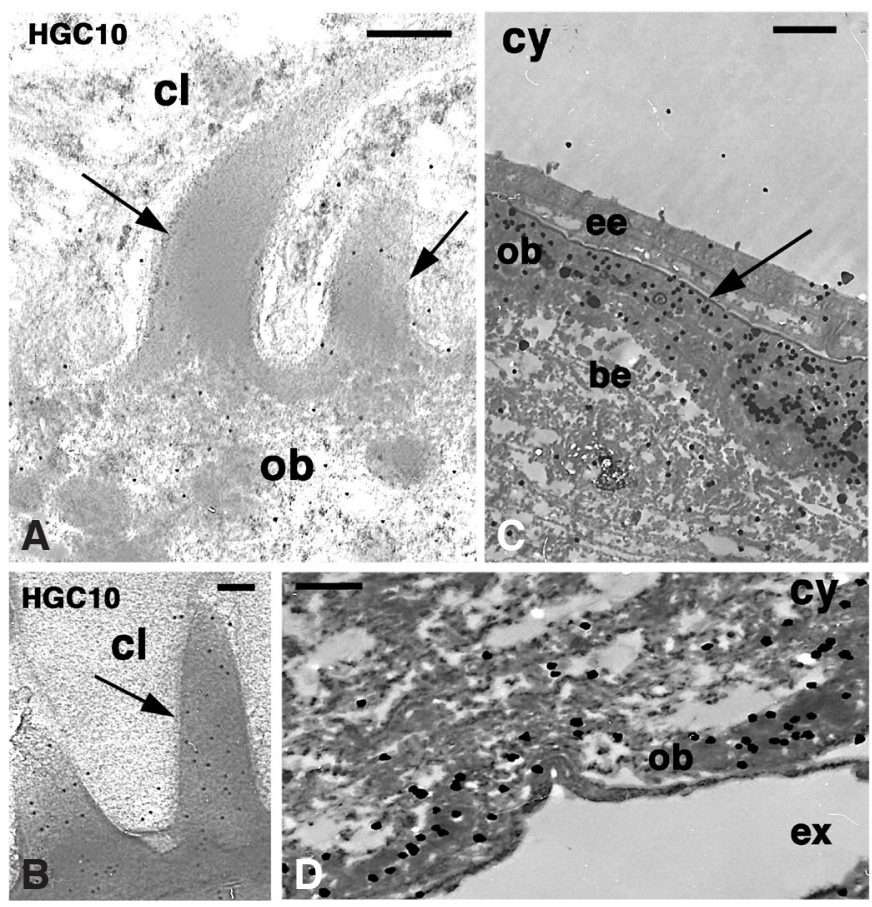

Fig. 6 (Left). Immunogold labeling in the lizard A. lineatopus for the HgGC10 beta-protein (A-B), and immunogold-silver intensified labeling for Sn-cys-1 beta-protein (cy) in the snake Liasis fuscus (C-D). (A) detail on the immunolabeled embryonic oberhautchen of a digit scale at stage 36, which spinulae (arrows) penetrate in the clear layer. Bar, $200 \mathrm{~nm}$. clear layer at stage 37. Bar, $100 \mathrm{~nm}$. (C) intense immunolabeling of the oberhautchen layer the arrow indicates the shedding linel for the cys-rich betaprotein, that is absent in the underlying beta-layers. Bar, $0.5 \mu \mathrm{m}$. (D) detail on the thin immunolabeled oberhautchen layer present in the inner (ventral) scale surface of an embryonic scales of the trunk. Bar, $250 \mathrm{~nm}$. Legends: cl, embryonic clear layer; ee, embryonic epidermis (= two periderm layers); bem beta-cells; ob, oberhautchen layer.

Fig. 7 (Right). Comparison between the immunolabeling for the Sn-cys-1 beta-protein (cy in A) and that for the pre-core box of corneous beta-proteins (PB in B) observed in trunk embryonic scales of the snake L. fuscus after silver intensification. (A) the irregular and large gold-silver intensified clumps appear exclusively present in the differentiating oberhautchen layer that shows a thickened membrane (arrows) separating it from the inner periderm. Bar, $0.5 \mu \mathrm{m}$. (B) the labeling with the general pre-core box antibody is only localized in the differentiating beta-cell layers forming underneath the oberhautchen (arrows indicated its slanted surface). Bar, $1 \mathrm{~m}$. Legends: be, beta-cell; ob, oberhautchen layer; p1, outer periderm; p2, inner periderm; pbe, pre-beta cell (= suprabasal cells not yet accumulating beta-corneous material). 


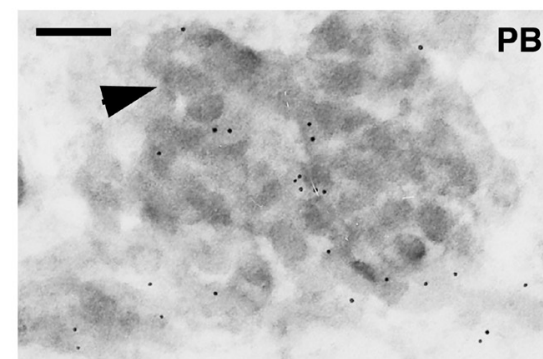

A

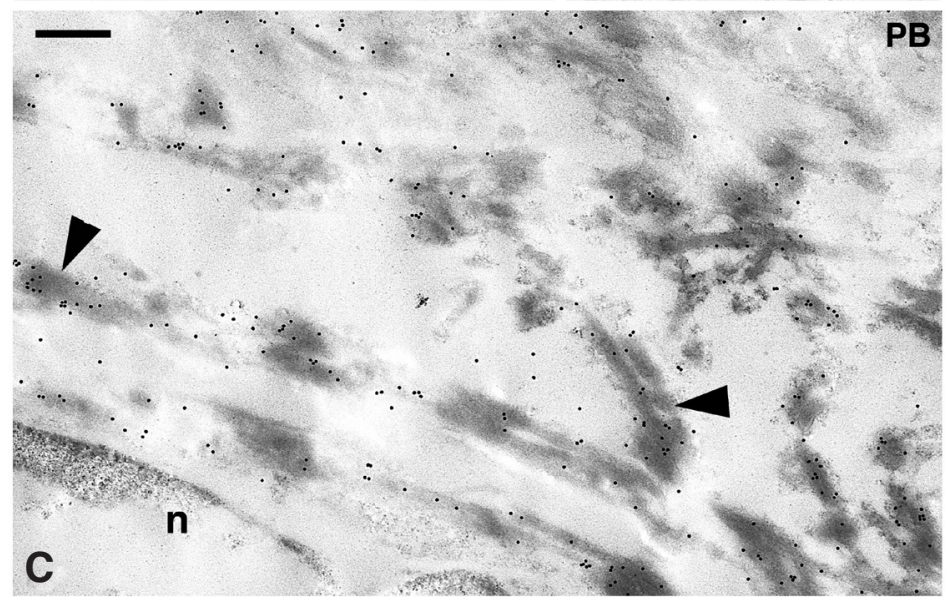

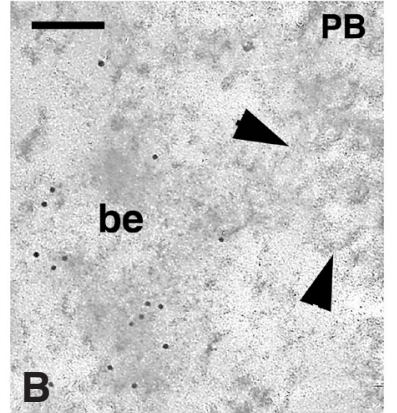

PB
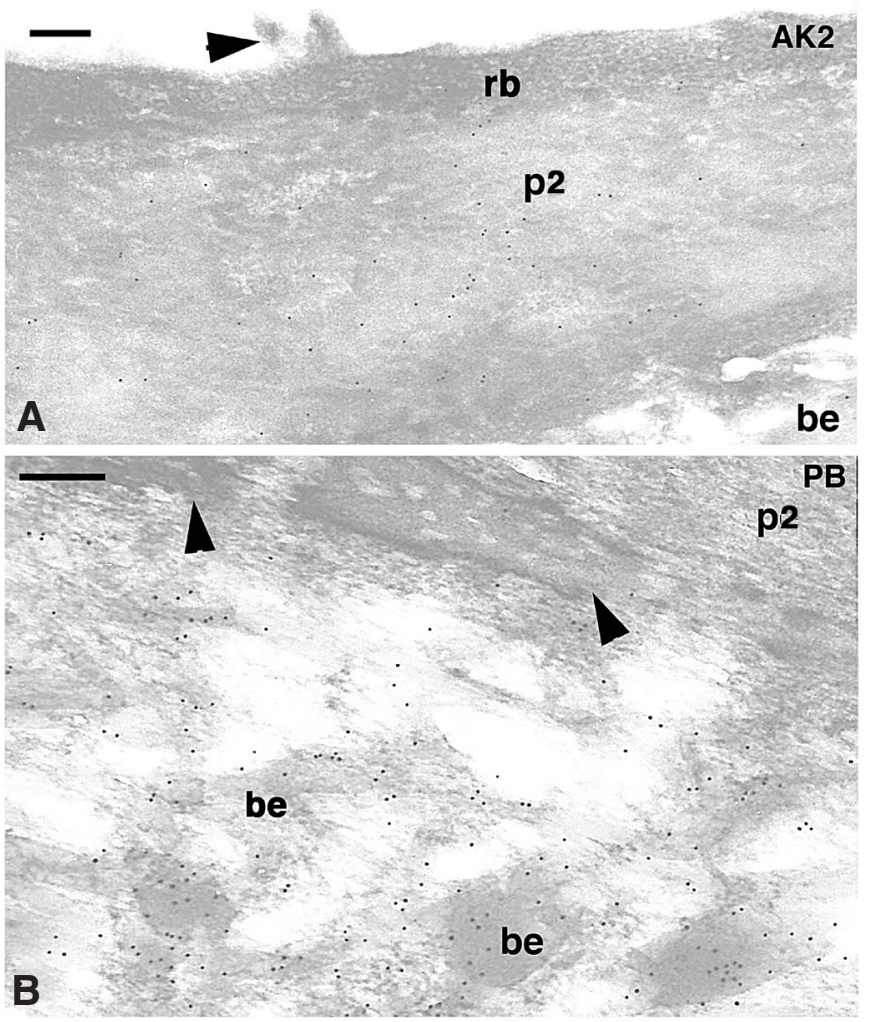

Fig. 8 (Left). Immunogold labeling for the turtle pre-core box antibody (PB) showing details of the epidermis of the carapace turtle T. hermanni at stage $23(\mathbf{A}, \mathbf{B})$ and in hatchlings $(\mathbf{C})$. (A) close-up on a reticulate corneous body (arrowhead) present in the inner periderm that shows a diffuse labeling. Bar, $100 \mathrm{~nm}$. (B) diffusely labeled and electron-pale beta-corneous material present in early differentiating beta-cell located undermeath the inner periderm. Arrowheads indicate that the corneous material forms a network of beta-corneous material at this early stage of differentiation destined to disappear as more corneous beta-proteins are packed up. Bar, $100 \mathrm{~nm}$. (C) Detail of a beta-cell (n, nucleus) accumulating immunolabeled bundles of beta-corneous material (arrowheads). Bar, $200 \mathrm{~nm}$.

Fig. 9 (Right). Immunogold details of $\boldsymbol{A}$. missippippiensis ventral epidermis at stage 28. (A) diffuse AK2 labeling for alpha-keratin over the reticulate bodies material sparsely distributed in the cytoplasm of inner periderm cell (p2). No labeling is present in the beta-corneous packets (be) seen in the beta layer forming below the inner periderm. Bar, $100 \mathrm{~nm}$. (B) Immunolabeled beta-corneous material (be) accumulating in the beta-layer formed underneath the inner periderm (p2, arrowhead indicate reticulate bodies). Bar, $200 \mathrm{~nm}$.

were poorly or un-labeled with this antibody (Fig. 7A).

An opposite labeling was observed after the application of the lepidosaurian pre-core box antibody to the embryonic epidermis of this snake. In fact, the latter antibody labeled intensely only the beta-cells produced underneath the oberhautchen layer, while the latter appeared negative to very diffusely labeled. The labeling was mainly directed to the pale corneous material bundles accumulating in beta-cells. No labeling to the pre-core box antibody was present in the outer periderm layers and in cells of the suprabasal layers localized underneath the beta-layer (Fig. 7B). These results indicate that oberahucthen and beta-cell corneous material contain different beta-proteins.

The immunostaining obtained using the antibody against the cysteine-rich-beta protein of snake (Sn-cys-1) did not produce any immunoabeling in lizard epidermis, indicating specificity only for snake oberhautchen.

\section{Ultrastructural immunocytochemistry for turtle and alligator epidermis}

The immunolabeling of the two periderm layers present in the turtle embryo showed absence of labeling for the pre-core box antibody. Only a diffuse labeling was associated with the large reticular bodies present in the inner periderm layer, the second layer formed from the surface (Fig. 8A). The first layer underneath the inner periderm contained small electron-pale beta-corneous packets labeled with some gold particles (Fig. 8B). In the shell epidermis of hatchlings, the spindle-shaped keratinocytes formed underneath the cornified periderm (Fig. 3E), showed an intense immuno-labeling in the bundles of beta-corneous material that were accumulating in the cytoplasm (Fig. 8C). No AK2 labeling was noted in these fusiform keratinocytes (data not shown).

In the two periderm layers of the alligator embryonic epidermis, the AK2 antibody produced a diffuse labeling in the second or inner periderm layer, in particular among or associated with the reticulate bodies containing coarse filaments (Fig. 9A). No AK2 labeling was seen in the beta cells formed underneath the inner periderm. Conversely in this initial beta-cell layer, the third formed from the embryonic surface, the electron-paler beta-corneous packets or bundles were labeled with the crocodilian pre-core box antibody while the inner periderm, containing reticulate bodies, remained mostly unlabeled (Fig. 9B). 
Double labeling detection of beta-proteins and alpha-keratins

In double labeling experiments, intended to show co-localization of alpha-keratins and beta-proteins, we utilized some combination of antibodies as indicated in the Material and Methods section. The reported observations and the purpose of the study are qualitative and no attempts to quantify the ratio between different gold particles over tonofilaments, desmosomes or on the mature corneous have been done. This was also due to the different penetration of gold particles with different diameter $(5-20 \mathrm{~nm})$ bonded to secondary antibodies, so that a quantitative determination would have produced results however biased.

In $A$. lineatopus epidermis, differentiating beta-cells seen under- neath the oberhautchen showed double labeling with prevalence for pre-core box positive beta-proteins (larger gold particles) and lower AE3-labeling for alpha-keratin (smaller gold particles, see Fig. $10 \mathrm{~A}, \mathrm{~B}$ ). The labeling appeared however un-even over the corneous material accumulating in these cells. In P. muralis, the beta-corneous bundles of early differentiating beta-cells appeared immunolabeled with fewer larger gold particles (10 nm, G28 antibody for beta-proteins) while a higher number of the smaller gold particles ( $5 \mathrm{~nm}$, AE3-positive or AK2 positive) for alpha-keratins was observed (Fig. 10C). The number of larger gold particles detected using the G28 antibody (for beta-proteins) over the smaller gold particles detected by the AK2 or AE3 antibodies (for alpha-keratins)
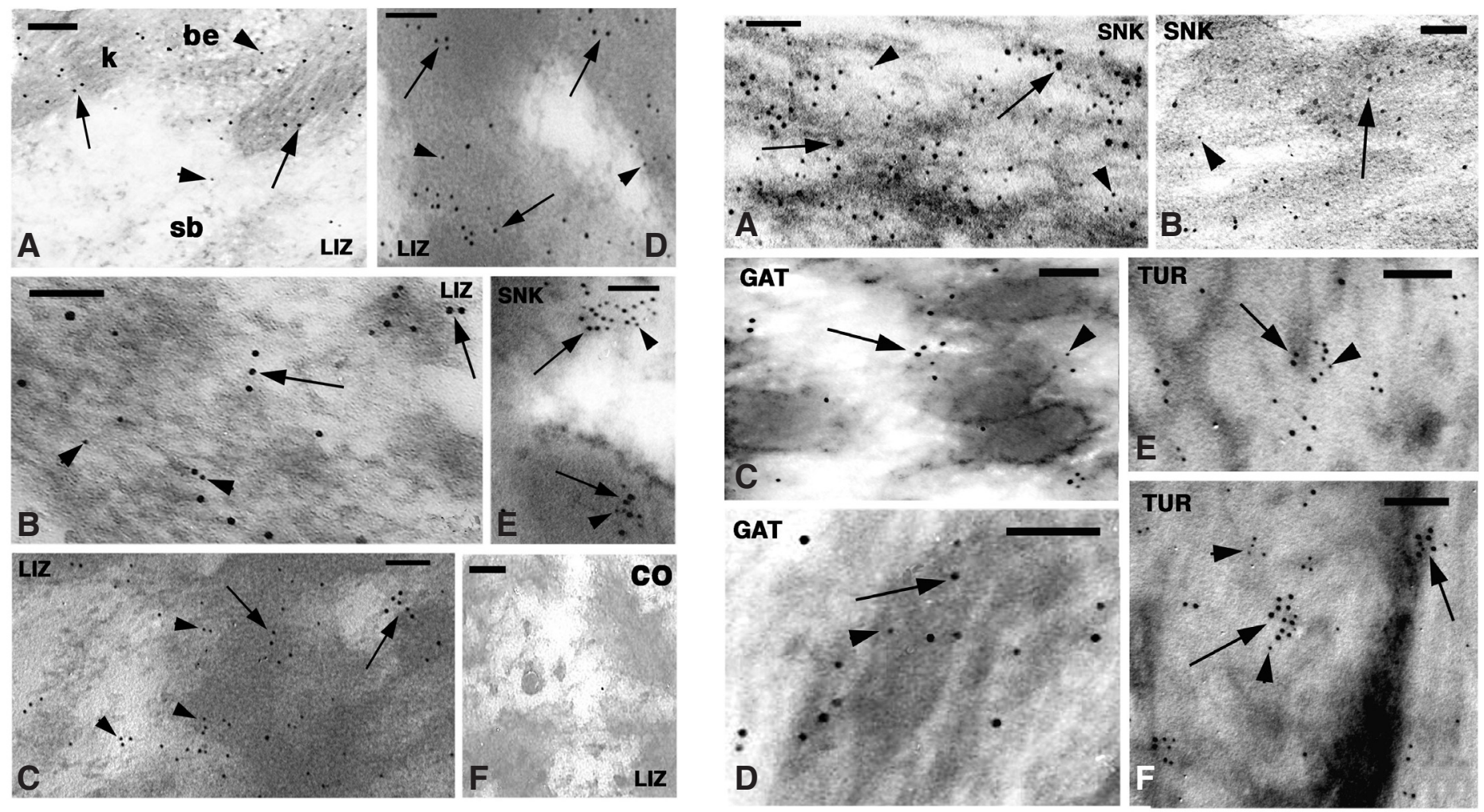

Fig. 10 (Left). Double labeling experiments showing co-localization of alpha-keratins (AE3 in A-B, AK2 in the remaining figures) and corneous beta-proteins (pre-core box in A,B, G28 in the remaining figures) in beta-cells of lizards (LIZ) and snake (SNK). Bars in all figures indicate 100 $\mathrm{nm}$. (A) Differentiating beta-cell (be) in A. lineatopus showing mainly beta-labeling (arrows) and few small gold particles for alpha-keratin (arrowhead) in corneous bundles. sb, suprabasal undifferentiated cell. (B) Other detail on beta-corneous material showing the prevalence of larger gold particles (arrows) indicating corneous beta-proteins and few small particles for alpha-keratins (arrowheads). (C) Early differentiating beta-cell of the tail epidermis of the lizard P. muralis shows numerous small gold particles (arrowheads) for alpha-keratins that prevail on the larger gold particles (arrows) indicating corneous beta-proteins. (D) In a more differentiated beta-cell of P. muralis the large particles for corneous beta-proteins (arrows) instead prevails on the small particles indicating alpha-keratins (arrowheads). (E) In the beta-corneous packets of a beta-cell present in trunk epidermis of the snake L. fuscus, large (arrows) and small (arrowheads) gold particles are equally present. (F) No labeling is present in this control section (CO) from a beta-cell of the tail epidermis in P. muralis.

Fig. 11 (Right). Double labeling details of differentiating beta-cells in the epidermis of snake (SNK, A,B) and alligator (GAT, C,D), and in the corneous layer of the carapace of hatchlings of tortoise (TUR, E,F), using the G28 antibody for corneous beta-proteins and the AK2 for alphakeratins. Bars in all figures represent $100 \mathrm{~nm}$. (A) Large beta-bundles showing similar number of small (arrowheads) and large (arrows) gold particles. (B) In a compact corneous material of a more differentiated beta-cell large particles for corneous beta-proteins (arrow) prevail over smaller particles (arrowhead) for alpha-keratins. (C) Sparse larger gold particles (arrow) indicating that corneous beta-proteins are prevalent on the small particles (arrowhead) for alpha-keratins in beta-packets. (D) Higher magnification detail on beta-corneous material showing co-localization of few small (arrowhead, indicating alpha-keratins) and more numerous large gold particles (arrows, indicating beta-proteins). (E) Areas featuring a similar number of small (arrowhead) and larger (arrow) particles. (F) Other corneous area showing prevalence of larger particles (arrows) indicating corneous beta-proteins, over smaller gold particles (arrowheads) for alpha-keratins. 
increased in the larger and amorphous beta-bundles observed in beta-cells with more advanced differentiation (Fig. 10D).

In beta-cells of the snake $L$. fuscus the double labeling was un-even over the dense beta-packets and both alpha-keratin (AK2 positive, small particles) and beta-proteins (G28 positive, large gold particles) were co-localized (Fig. 10E). Control sections of the same areas in both lizards and snake showed no labeling (Fig. $10 \mathrm{~F})$. In the larger bundles of differentiating snake beta-cells or in more mature beta-cells, also the beta-keratin labeling tended to be prevalent on the alpha-keratin labeling (Fig. $11 \mathrm{~A}, \mathrm{~B}$ ).

The observations on double-labeled beta-cells of embryonic skin of alligator showed an irregular density of gold particles over the amorphous beta-bundles, with prevalence of larger particles indicating beta-proteins (G28 antibody) over the less frequent smaller particles indicating alpha-keratin (AK2, see Fig. 11 C,D). Finally, the double-labeling experiment in the packed beta-corneous material of pre-corneous keratinocytes of the turtle carapace showed a diffuse but un-even labeling. In some regions of the corneous bundles, smaller gold particles indicating alpha-keratin localization (AK2 positive) were seen in similar number than that of the larger gold particles for beta-proteins (G28 positive) (Fig. 11E). In other regions however the larger particles were instead predominant over the smaller gold particles, suggesting a prevalence of beta-proteins over detectable alpha-keratins (Fig. 11F). Controls sections were unlabeled (data not shown).

\section{Discussion}

\section{Characteristics of cornification in reptilian scales}

The present study has shown that specific glycine-cysteine-rich corneous beta-proteins are synthesized in the oberhautchen layer in preparation for the skin shedding that characterizes snakes and lizards. Like in other amniotes (Kalinin et al., 2002; Byrne et al., 2003), also in reptilian scales the differentiation of the epidermis takes place by the deposition of proteins over the initial keratin meshwork and on the plasma membrane of corneocytes. The formation of the beta-corneous layer derives from the deposition of Corneous beta-proteins and the following masking or degradation of alpha-keratins, and not on the replacement of alpha-keratin with beta-keratin as previously indicated (Baden and Maderson, 1970; Maderson, 1985; Chang et al., 2009).

In mammalian embryos, beneath one layer of periderm other 1-3 intermediate layers are formed before the first true granular layer differentiates (Weiss and Zelickson, 1975a,b). The periderm later matures into a dead cell layer after expressing some corneous proteins such as loricrin, filaggrin and small proline-rich proteins, in addition to acidic keratins of 40-44 kDa (Hardmann et al., 1998; Akiyama et al., 1999; Byrne et al., 2003).

A similar process also occurs in reptiles and birds where, aside acidic keratins, other corneous proteins are produced beneath the periderm. The best known, non-keratin proteins produced in reptiles and birds are small proteins with a central region rich in beta-sheets, formerly termed beta- or phi-keratins because they form 3-4 nm thick filaments (Wyld and Brush, 1983; Fraser and Parry, 1996; Sawyer et al., 2000). However, these specialized proteins have a gene structure and amino acid composition very different from those of alpha-keratins while they have the same role of mammalian corneous proteins and keratin associate proteins. Like filaggrin or loricrin in the epidermis, or Keratin Associated
Proteins in hairs, corneous beta-proteins are synthesized in upper suprabasal layers in scale epidermis and mix with the tonofilaments turning them into an amorphous mass. Further genomic studies have indicated that "beta-keratin" genes are localized within the Epidermal Differentiating Complex (EDC) of the chick and lizard, clustered with other keratin associated or corneous proteins such as filaggrin, loricrin, involucrin, cornulin, and S100 proteins (Vanhoutteghem et al., 2008; Mlitz et al., 2014; Strasser et al., 2014). The latter study further indicates that beta-keratins represent a type of corneous proteins specific for sauropsid hard epidermis and characterized by a central beta-pleated region but different, also in their genomic localization, from the intermediate filament (alpha) keratins.

The presence of one intron between the first (non-coding) and the second (coding) exon, typical for most Corneous beta-proteins genes, is a shared charasteristic with genes of the EDC coding for other proteins indicated as SEDCs (Simple Epidermal Differentiation Complex proteins) within the chick and lizard EDC, such as Late Cornified Proteins, Small Proline Rich Proteins, Cornulin and Loricrin (Mlitz et al., 2014; Strasser et al., 2014). These recent molecular studies have further indicated that these proteins formerly indicated as beta-keratins are specialized corneous proteins of sauropsids.

\section{Changes from embryonic to adult epidermis in reptilian scales}

The present immunocytochemical study has detected glycinerich or glycine-cysteine-rich corneous beta-proteins in sub-periderm layers of reptiles in preparation to hatching. The present study extends to the embryonic epidermis the new interpretation on the mechanism of cornification present in reptilian epidermis and its appendages outlined above. The present double-labeling study for alpha-keratin and corneous beta-proteins co-localization further supports this new interpretation on the process of cornification in reptiles, indicating that the process takes place since the initial embryonic stages of skin development (Fig. 12).

In particular, the present immunogold study together previous biochemical analysis (Alibardi and Toni, 2006; Toni et al., 2007) demonstrate that the outer and inner periderm layers contain acidic alpha keratins (AK2-positive) while only the following layers accumulate corneous beta-proteins, a process similar to that occurring in adult epidermis. Since the above studies have indicated that these proteins are initially basic when synthesized from ribosomes, it is likely that, aside other chemical bonds, acidic alpha-keratins and basic corneous beta-proteins also interact by electrostatic attractions.

The formation of a stratified epidermis is a relatively late event in skin formation in reptiles, about 1-3 weeks before hatching, leading to the differentiation of the definitive epidermal layers. This occurs from embryonic stage 22-23 in turtles (Alibardi and Thompson, 1999; Alibardi, 1999; Alibardi and Dipietrangelo, 2005) and at a later stage (24) form 2-5 cell layers of stratified beta-cells. Also in the alligator a stratified beta-corneous layer is formed around 60-65 days of development, or at stage 24 in crocodiles (Richardson et al., 2000; Alibardi and Thompson, 2001). Therefore, in both turtles and crocodilians a stratified corneous layer is ready for protection before hatching.

The complete differentiation of the beta-layer in lizards occurs at about 1 week before hatching when intra-ovo shedding occurs (Dhouailly and Maderson, 1984; Alibardi, 1998). In the embryo of the lizard Anolis carolinensis, immunoreactivity for corneous 

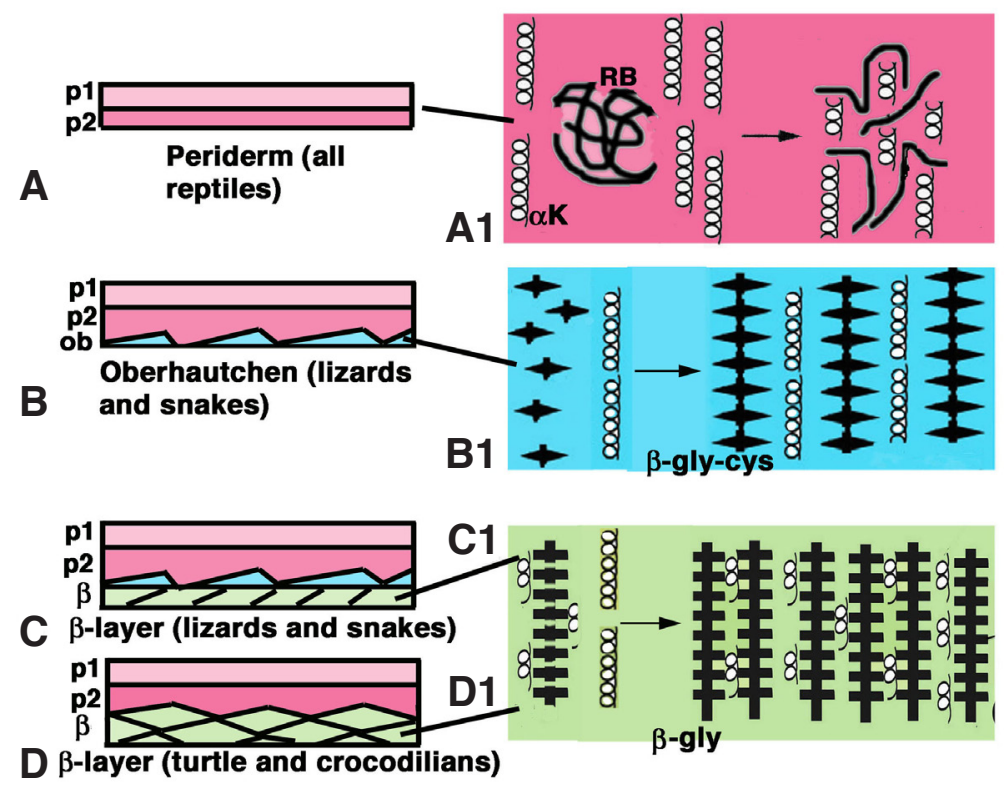

Fig. 12. Schematic drawing representing the difference in protein aggregation in the periderm (A, A1), oberhautchen layer of lepidosaurians (B, B1), and beta-layers produced underneath the embryonic layers (C, C1). In the inner periderm (p2) more than in the outer periderm (p1) reticulate bodies (RB) mix with acidic alpha-keratins; see arrow in (A1) during "keratinization." In the oberhautchen (ob) glycine-cysteine-rich corneous beta-proteins accumulate; see arrow in (B1) while in the following beta-layers ( $\beta$ ) of lizards, snakes, turtles and crocodilians, glycine-rich corneous beta-proteins prevail and alpha-keratins become masked or degraded; see arrow in (C1).

beta-proteins (beta-keratins) of 21-25 kDa appears at about 30 days of development, 1-2 weeks before hatching (Carver and Sawyer, 1987). Before the stratification of the epidermis with the formation of the beta-layer, only alpha-keratins of 50-61 kDa are present in the three-layered epidermis. As shown in the present study, it is likely that at least some of these keratins are associated or are true components of the embryonic organelles indicated as reticulate bodies (Fig. 12). As cornification of the periderm takes place, the strands of coarse filaments loose their definition and diameter, initially of $25-50 \mathrm{~nm}$, to become irregular and mixing with other unknown periderm proteins and cytoplasmic acidic keratins. Differently from mammalian periderm (Akiyama et al., 1999; Byrne et al., 2003), no information on reptilian periderm proteins is presently available although our study suggests the presence of acidic proteins (AK2 positive) and of some corneous beta-proteins in tortoise reticulate corneous bodies (see also Alibardi, 2008).

The formation of a definitive process of cornification in reptilian epidermis appears very anticipated with respect to hatching in order to complete the formation of the beta-layer of the first epidermal generation that has to face the dry and harsh terrestrial environment encountered after hatching (Dhouailly and Maderson, 1984; Alibardi, 2003, 2008). The corneous beta-proteins produced underneath the second or third subperidermal layer in the epidermis of lizards, turtles and crocodilians appear rich in glycine since most of the proteins recognized by the pre-core box antibody belong to this subclass (Alibardi, 2013b). Therefore basic corneous betaproteins mostly mask the initial acidic alpha-keratins produced in keratinocytes of subperidermal layers. Differently from turtles and crocodilians, the lepidosaurians (lizards and snakes) have evolved a cyclical shedding mechanism to shed their epidermis and allow somatic growth (Maderson et al., 1998). The deposition of specialized cysteine-glycine rich corneous beta-proteins, such as HgGC10 in the lizard $A$. lineatopus, or Sn-cys-1 in the snake $L$. fuscus in the oberhautchen layer marks the formation of the shedding layer. This process starts in the differentiating embryonic oberhautchen layer in preparation for the first (in ovo) shedding that in this species occurs 1-2 weeks before hatching (Alibardi, 2008; Alibardi and Thompson, 2003). The lack of immunoreactivity with the embryonic (and adult) oberhautchen of lizards and with the epidermal layers of turtle and alligator indicates that this beta-protein is a specialization of snake epidermis for shedding.

After the oberhautchen layer is formed beneath the periderm in snakes, other beta proteins rich in glycine are also produced in the following beta-layer of snakes at 10-25 days before hatching, according to the species (Alibardi, 2002; Alibardi and Thompson, 2003; Swadzba and Rupik, 2010). The differentiation of a resistant beta-layer is very important in the protection of the hatchlings for both mechanical antiwearing and as protection of the underlying, more delicate mesos and alpha-layers that are essential for life on land as they represent the barrier against water-loss (Maderson, 1985; Dhouailly and Maderson, 1984; Chang et al., 2009).

\section{Materials and Methods}

\section{Fixation and antibody selection}

Embryos from different reptiles were collected and prepared for embedding in Resins as indicated in previous studies. Only stages known to contain both embryonic and the initial layers of the definitive epidermis were utilized, and two samples were analyzed in each species here utilized. These were stage 38 in the lizard Podarcis muralis (Alibardi, 1998), stages 36 and 37 in the lizard Anolis lineatopus (Alibardi, 2012), stage 37 in the lizard Lampropholis guichenoti (Alibardi and Thompson, 1998), stage 36 in the snake Liasis fuscus (Alibardi and Thompson, 2003), stages 23 and 24, and hatchlings in the turtle Testudo hermanni (Alibardi and Dipietrangelo, 2005), and stage 28 in the alligator Alligator missippippiensis (Alibardi and Thompson, 2002). As indicated by the above studies, the general appearance of the skin and the epidermal histology in these selected stages showed the cytological transition from the embryonic to the definitive epidermis, and in particular contained the differentiating keratinocytes of the beta-layer in lizards and snakes, and of the corneous (beta) layer in turtles and alligator.

From the collected embryos small pieces of the skin from the ventral body or tail regions in lizards, snakes and alligator, or from the marginal carapace of the turtle, were fixed at $0-4^{\circ} \mathrm{C}$ for $5-8$ hours in $4 \%$ freshly made paraformaldehyde in $0.1 \mathrm{M}$ phosphate buffer at $\mathrm{pH} 7.4$. These tissues were dehydrated in ethanol $80 \%, 90 \%$, immersed in the hydrophilic Resin Bioacryl for 3-4 hours until tissues sank (an indication of complete embedding) before curing the resin containing the samples for 2 days at $0-4^{\circ} \mathrm{C}$ under UV irradiation (Scala et al., 1992).

Using an ultramicrotome, sections of $2-5 \mu \mathrm{m}$ were collected on glass slides for the histological staining using $1 \%$ Toluidine blue. Other sections were instead collected over chromoallume-gelatin-coated slides for the following immunocytochemical detection. Immunocytochemistry for both light and electron microscopy was performed using rabbit polyclonal antibodies produced against specific epitopes characteristics for the pre-core box region of turtle corneous beta-proteins (GVARPCPVTGTCNEPCVRQC), crocodilian corneous beta-proteins (GIACPRPFADSCNEACIRQC), and for lepidosaurian corneous beta-proteins (TSAASLGILSGASPSCINQI; Alibardi, 2013a). These three epitopes represent the more conserved sequences found among most of corneous beta-proteins analyzed in turtles, 
crocodilians and lepidosaurians, and therefore should detect these proteins in the beta-layer (hard layer) also of the embryonic scales in case these proteins are synthesized in embryos. Another antibody, here indicated as Sn-cys-1 (Snake cysteine-rich-1), was produced against another epitope (SSGGSSRLRYFPCSPCSPCK) present in a glycine-cysteine-rich corneous beta protein of the epidermis of the snake Panthoteris guttatus (Dalla Valle et al., 2009). A further antibody directed against the epitope of the glycinecysteine-rich corneous beta protein HgGC10 (VPSCSSTPCIGIGAQR, Alibardi, 2012) was also utilized for immune labeling in the embryo of the lizard Anolis lineatopus.

The antibodies directed against the above five epitopes were produced in rabbits through a Biotechnology Company (Davids Biotechnologie, Regensburg, Germany). The Company synthesized the indicated peptides, immunized the rabbits, purified the antibodies by affinity chromatography, and tested the reactivity of the immune serum by ELISA according to their protocols. The ELISA test revealed a strong reactivity against the immunogen peptides utilized for immunization, indicating specificity.

For double-labeling experiments, a rabbit antibody against an epitope of a turtle alpha-keratin (LVDGKIVSSQVQSVEERPAK, see Dalla Valle et al., 2013; Alibardi, 2013a) or a mouse antibody against alpha-keratins tonofilaments of mammalian and lizard keratinocytes (Alibardi, 2003), indicated as AE3, were utilized in conjunction with goats (G28) or rabbits (Pre-core box) antibodies (see below).

\section{Immunocytochemistry}

Immunofluorescence analysis was carried out after pre-incubation for

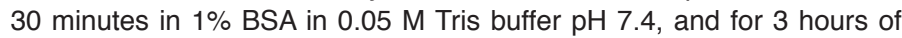
incubation in the primary antibody $(1: 100$ or $1: 200)$ at room temperature. In controls, the primary antibody was omitted from the incubating solution. Previous studies testing the specificity of these antibodies indicated that immunonegative results were obtained by pre-absorption of the antibodies with their antigens (Alibardi, 2013a). After rinsing in the above buffer for 10 minutes, the sections were incubated for 1 hour at room temperature with a Rhodamine-conjugated anti-rabbit antibody (TRITC, Sigma, diluted $1: 100$ ), rinsed in buffer and mounted in an anti-fading medium (Fluoroshield, Sigma). Slides were observed under a fluorescence microscope equipped with a Rhodamine filter, and pictures were collected with a digital camera into a computer using an Adobe Photoshop Program.

For electron microscopy immunocytochemistry, 50-90 nm thick sections were collected with an ultramicrotome on nickel grids, and pre-incubated for 10 minutes in $0.05 \mathrm{M}$ TRIS-HCl buffer at $\mathrm{pH} 7.4$, containing $1 \%$ Cold Water Fish Gelatin. The sections were then incubated for 3 hours at room temperature in primary antibodies diluted 1:200 in buffer while in controls the primary antibody was omitted in the first incubation step. Sections were rinsed in buffer and incubated for 1 hour at room temperature with antirabbit Gold-conjugated secondary antibodies (Sigma, USA, $10 \mathrm{~nm}$ gold particles). After this immunolabeling, grids were left to dry for at least 10 minutes. Some immunogold-labeled sections were further treated with the Silver-enhancement procedure developed by British Biocell International (BBB, Bristol, UK), in order to increase the size of gold particles and allow the detection of labeled cells at lower magnification. This procedure allowed the detection at low magnification of immunoreactive cells present in different layers of the epidermis. The suggested intensification method followed the manufacturer instructions (BBI, SEKB250) with intensification periods of 6-12 minutes.

For double-labeling experiments on lizard sections, after the application of the primary rabbit pre-core-box antibody and of the anti-rabbit secondary 10 or $20 \mathrm{~nm}$ gold-conjugated antibody, the sections were further immunolabeled with a primary mouse AE3 antibody (a generous gift from Dr. T.T. Sung, NY University, USA, see Sun et al., 1983) at 1: 50 dilution in buffer, rinsed, and incubated with a secondary anti-mouse $5 \mathrm{~nm}$ gold antibody. In other experiments, the primary AK2 rabbit antibody against an epitope present in a turtle alpha-keratin (Dalla Valle et al., 2013; Alibardi, 2013a) was later tagged by a secondary antibody conjugated with $5 \mathrm{~nm}$ gold particles. This labeling was also utilized in conjunction with a goat polyclonal antibody (G28) produced against a beta-keratin isolated by electrophoresis from chick scale, and was detected by a secondary anti-goat $10 \mathrm{~nm}$ gold conjugated antibody. The G28 antibody was a generous gift from Dr. R.H. Sawyer, University of South Carolina, Columbia, USA (see Sawyer et al., 2000). In conclusion, the double-labeling experiments combined rabbit (10 or $20 \mathrm{~nm}$ gold) and mouse (5 $\mathrm{nm}$ gold) antibodies, or rabbit ( $5 \mathrm{~nm}$ gold) and goat (10 $\mathrm{nm}$ gold) antibodies.

After the incubation with the secondary antibodies, the grids were rinsed in buffer, dried, stained for 5 minutes with $2 \%$ uranyl acetate, and observed under the electron microscope Zeiss $10 \mathrm{C} / \mathrm{CR}$ operating at $60 \mathrm{kV}$. Pictures were taken with either classical photography or by a digital camera.

\section{Acknowledgments}

Most of the present study was self-supported and with small Grant from the Italian Ministry of Education (2008-2010).

\section{References}

AKIYAMA, M., SMITH, L.T., YONEDA, K., HOLBROOK, A.K., HOHL, D., SHIMIZU, $H$. (1999). Periderm cells form cornified cell envelope in their regression process during human epidermal development. J. Inv. Dermatol. 112: 903-909.

ALIBARDI, L. (1998). Differentiation of the epidermis during scale formation in embryos of lizard. J. Anat. 192: 173-186.

ALIBARDI, L. (2000). Ultrastructural localization of alpha-keratins in the regenerating epidermis of the lizard Podarcis muralis during formation of the shedding layer. Tiss. Cell 32: 153-162.

ALIBARDI, L. (1999). Differentiation of the epidermis of neck, tail and limbs in the embryo of the turtle Emydura macquarii. Belg. J. Zool. 129: 379-392.

ALIBARDI L. (2002). Ultrastructure of the embryonic snake skin and putative role of histidine in the differentiation of the shedding complex. J. Morphol. 251: 149-168.

ALIBARDI, L. (2003). Adaptation to the land: the skin of reptiles in comparison to that of amphibians and endotherm amniotes. J. Exp. Zool. 298B, 12-41.

ALIBARDI, L. (2008). Embryonic keratinization in vertebrates in relation to land colonization. Acta Zool. 90: 1-17

ALIBARDI, L. (2012). Immunolocalization of keratin-associated beta proteins (betakeratins) in developing epidermis of lizard reveals that adhesive setae contain glycine-cysteine-rich proteins. J. Morphol. 274: 97-107.

ALIBARDI, L. (2013a). Cornification in reptilian epidermis occurs through the deposition of keratin associated beta proteins (beta-keratins) onto a scaffold of intermediate filament keratins. J. Morphol. 274: 175-193.

ALIBARDI, L. (2013b). Immunoreactivity to the pre-core box antibody shows that most glycine-rich beta-proteins accumulate in lepidosaurian beta-layer and in the corneous layer of crocodilian and turtle epidermis. Micron (Early view).

ALIBARDI, L., DIPIETRANGELO, L. (2005). Differentiation of the epidermis of scutes in embryos and juveniles of the tortoise Testudo hermanni with emphasis on beta-keratinization. Acta Zool. 86: 205-216.

ALIBARDI, L., THOMPSON, M.B. (1998). Epidermal differentiation in the developing scales of embryos of the Australian scincid lizard Lampropholis guichenoti. J. Morphol. 241: 139-152.

ALIBARDI, L., THOMPSON, M.B., (1999). Morphogenesis of shell and scutes in the turtle Emydura macquarii. Austral. J. Zool. 47, 245-260.

ALIBARDI L., THOMPSON, M.B. (2001). Fine structure of the developing epidermis in the embryo of the American alligator (Alligator mississippiensis, Crocodilia, Reptilia). J. Anat. 198, 265-282.

ALIBARDI L., THOMPSON, M.B. (2002). Keratinization and ultrastructure of late embryonic stages in the alligator (Alligator mississippiensis). J. Anat. 201: 71-84.

ALIBARDI, L., THOMPSON, M.B. (2003). Epidermal differentiation during ontogenesis and after hatching in the snake Liasis fuscus (Pythonidae, Serpentes, Reptilia). with emphasis on the formation of the shedding complex. J. Morphol. 256: 256, 29-51.

ALIBARDI L., TONI, M. (2006). Cytochemical, biochemical and molecular aspects of the process of keratinization in the epidermis of reptilian scales. Prog. Histoch. Cytoch. 40: 73-134.

ALIBARDI, L., DALLA VALLE, L., NARDI, A., TONI, M. (2009). Evolution of hard proteins in the sauropsid integument in relation to the cornification of skin derivatives in amniotes. J. Anat. 214: 560-586. 
BADEN, H.P., MADERSON, P.F. (1970). Morphological and biophysical identification of fibrous proteins in the amniote epidermis. J. Exp. Zool. 174: 225-232.

BYRNE, C., HARDMAN, M., NIELD, K. (2003). Covering the limb- formation of the integument. J. Anat. 202: 113-124.

CARVER, W.E., SAWYER, R.H. (1987). Development and keratinisation of the epidermis of the common lizard, Anolis carolinensis. J. Exp. Zool. 243: 435-443.

CHANG, C., Wu, P., BAKER, R.E., MAINI, P.K., ALIBARDI, L., CHUONG, C.M. (2009). Reptile scale paradigm. Evo-devo, pattern formation and regeneration. Int. J. Dev. Biol. 53: 813-826.

DALLA VALLE, L., NARDI, A., ALIBARDI, L., 2009a. Isolation of a new class of cysteine-glycine-proline rich beta-proteins (beta-keratins) and their expression in snake epidermis. J. Anat. 216: 356-367.

DALLA VALLE, L., MICHIELI, F., BENATO, F., SKOBO, T., ALIBARDI, L. (2013). Molecular characterization of alpha-keratins in comparison to associated betaproteins in soft-shelled and hard-shelled turtles produced during the process of epidermal differentiation. J. Exp. Zool. 320B: 428-441.

DHOUAILLY, D., MADERSON, P.F.A. (1984). Ultrastructural observations on the embryonic development of the integument of Lacerta muralis (Lacertilia, Reptilia). J. Morphol. 179: 203-228.

ECKHART L, LIPPENS S, TSCHACHLER E, DECLERCQ W. (2013). Cell death by cornification. Biochim Biophys Acta 1833: 3471-3480.

ELIAS, P.M., CHOI, E.H. (2005). Interactions among stratum corneum defensive functions. Exp. Dermatol. 14: 719-726.

FRASER, R.D.B., PARRY, D.A.D. (1996). The molecular structure of reptilian keratin. Intern. J. Biol. Macromol. 19, 207-211.

HARDMAN, M.J., SISI, P., BANBURY, DN., BYRNE, C. (1998). Patterned acquisition of skin barrier function during development. Development 125, 1541-1552.

KALININ, A.E., KAJAVA, A.V., STEINERT, P.M. (2002). Epithelial barrier function: assembly and structural features of the cornified cell envelope. BioEssays 24:789-800.

KLINGE, EM., SYLVESTRE, YR., FREEDBERG, IM., BLUMEMBERGI, M. (1987). Evolution of keratin genes: different protein domains evolve by different pathways. J. Mol. Evol. 24: 319-329.

KOSTER, M.I., ROOP, D.R. (2004). Genetic pathways required for epidermal morphogenesis. Eur. J. Cell Biol. 83: 625-629.

KURAITIS, K.V., BOWERS, R.R. (1978). An ultrastructural study of periderm granules in the regenerating feather of the jungle fowl. Cell Tiss. Res. 192: 319-326.

MADERSON, P.F.A., 1972. When, why and how: some speculations on the evolution of the vertebrate integument. Am. Zool. 12: 159-171.

MADERSON, P.F.A. (1985). Some developmental problems of the reptilian integument In Biology of Reptilia: Development, (eds. Gans C, Billett F, Maderson PFA), pp. 525-598. New York: Johm Wiley \& Sons.

MLITZ, V., STRASSER, B., JAEGER, K., HERMANN, M., GHANNADAN, M.,
BUCHBERGER, M., ALIBARDI, L., TSCHACHLER, E., ECKHART, L. (2014). Trichohyalin-like proteins have evolutionarily conserved roles in the morphogenesis of skin appendages. J. Inv. Dermatol. 134: 2685-2692

RICHARDSON, K.C., PARK, J.Y., WEBB, J.W., MANOLIS, S.C. (2000). Skin histology of embryonic and hatchling estuarine and australian freshwater crocodiles. In: Crocodilian biology and evolution. Eds. Grigg G, Seebacher F, Franklin CE.; Surrey Beatty \& Sons. Chipping Norton, NSW, pp 188-196.

SAWYER, R.H., GLENN, T.C., FRENCH, J.O., MAYS, B., SHAMES, R.B., BARNES G.L., RHODES, W., ISHIKAWA, Y. (2000). The expression of beta $(\beta)$ keratins in the epidermal appendages of reptiles and birds. Am. Zool. 40: 530-539.

SAWYER, R.H., KNAPP, L.W. (2003). Avian skin development and the evolutionary origin of feathers. J. Exp. Zool. 298B: 57-72.

SCALA, C., CEMACCHI, G., FERRARI, C., PASQUINELLI, G., PREDA, P., MANARA G.C. (1992). A new acrylic resin formulation: a useful tool for histological, ultrastructural, and immunocytochemical investigations. J. Histochem. Cytochem. 40: 1799-1804.

STAUDT, K., BOHME, W., BAUMGARTNER, W. (2012). Comparative investigations of the sandfish's beta-keratin (Reptilia: Scincidae: Scincus scincus). Part 2: glycan based friction reduction. J. Biomim. Biomat. Tiss. Engin. 16: 1-9.

STEINERT, P.M., FREEDBERG, I.M. (1991). Molecular and cellular biology of keratins In Physiology, biochemistry, and molecular biology of the skin, (ed Goldsmith LA), pp. 113-147. New York: Oxford University Press.

STRASSER, B., MLITZ, V., HERMANN, M., RICE, R.H., ALIBARDI, L., TSCHACHLER E., ECKHART, L. (2014). Evolutionary origin and diversification of epidermal barrier proteins in amniotes. J. Mol. Evol. 31:3194-3205.

SWADZBA, E., RUPIK, V. (2010). Ultrastructural studies of epidermis keratinization in grass snake embryos of Natrix natrix L. (Lepidosauria, Serpentes) during late embryogenesis. Zoology 113: 339-360.

SUN, T.T., EICHNER, R., NELSON, W.G., TSENG, S.C.G., WEISS, R.A., JARVINEN M., WOODCOCK-MITCHELL, J. (1983). Keratin classes: molecular markers for different types of epithelial differentiation. J. Inv. Dermatol. 81: 109s-115s.

TONI, M., DALLA VALLE, L., ALIBARDI, L. (2007). Hard (Beta-)keratins in the epidermis of reptiles: composition, sequence, and molecular organization. J. Prot. Res. 6: 3377-3392.

WEISS, L.W., ZELICKSON, A.S., 1975a. Embryology of the epidermis: ultrastructural aspects II. Acta Dermatovener. 55, 321-329.

WEISS, L.W., ZELICKSON, A.S. (1975b). Embryology of the epidermis: ultrastructural aspects III. Acta Dermatovener. 55: 431-442.

VANHOUTTEGHEM, A., DJIAN, P., GREEN, H. (2008). Ancient origin of the gene encoding involucrin, a precursor of the cross-linked envelope of epidermis and related epithelia. Proc. Natl. Acad. Sci. USA 105: 15481-15486.

WYLD, J.A., BRUSH, A.H. (1983). Keratin diversity in the reptilian epidermis. J. Exp. Zool. 225: 387-396. 


\section{Further Related Reading, published previously in the Int. J. Dev. Biol.}

Sexual dimorphism of AMH, DMRT1 and RSPO1 localization in the developing gonads of six anuran species

Rafal P. Piprek, Anna Pecio, Katarzyna Laskowska-Kaszub,Jacek Z. Kubiak and Jacek M. Szymura

Int. J. Dev. Biol. (2013) 57: 891-895

Dual embryonic origin of the hyobranchial apparatus in the Mexican axolotl (Ambystoma mexicanum)

Asya Davidian and Yegor Malashichev

Int. J. Dev. Biol. (2013) 57: 821-828

Clonal analyses in the anterior pre-placodal region: implications for the early lineage bias of placodal progenitors

Sujata Bhattacharyya and Marianne E. Bronner

Int. J. Dev. Biol. (2013) 57: 753-757

Amphibian interorder nuclear transfer embryos reveal conserved embryonic gene transcription, but deficient DNA replication or chromosome segregation

Patrick Narbonne and John B. Gurdon

Int. J. Dev. Biol. (2012) 56: 975-986

Origins of $\mathrm{Cdx} 1$ regulatory elements suggest roles in vertebrate evolution

Stephen J. Gaunt and Yu-Lee Paul

Int. J. Dev. Biol. (2011) 55: 93-98

Reptile scale paradigm: Evo-Devo, pattern formation and regeneration

Cheng Chang, Ping Wu, Ruth E. Baker, Philip K. Maini, Lorenzo Alibardi and Cheng-Ming Chuong

Int. J. Dev. Biol. (2009) 53: 813-826

Proteomics analysis of regenerating amphibian limbs: changes during the onset of regeneration

Michael W. King, Anton W. Neff and Anthony L. Mescher

Int. J. Dev. Biol. (2009) 53: 955-969

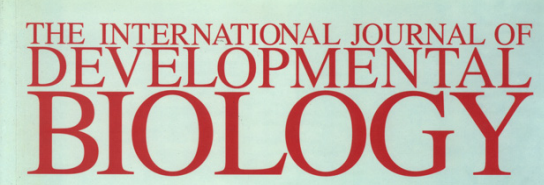

Volume 40 No. 4 August 1996

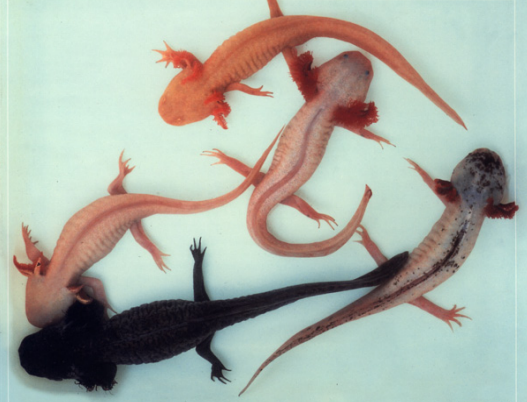

Developmental Biology of Urodeles
5 yr ISI Impact Factor $(2013)=2.879$

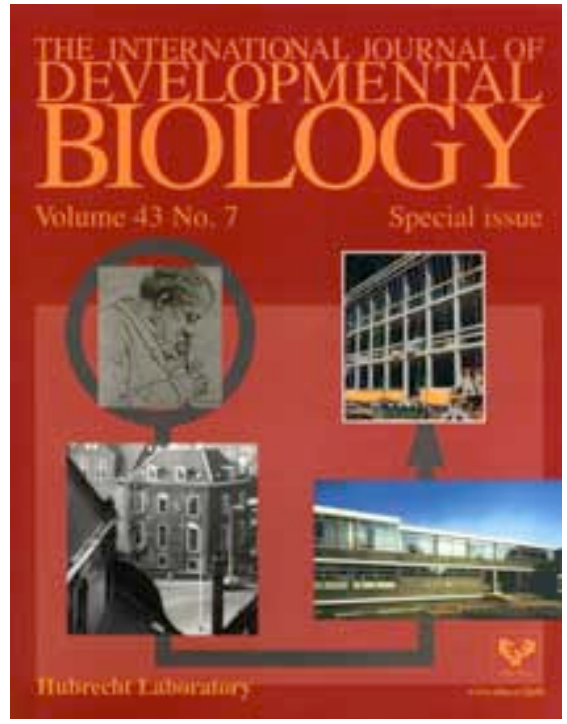

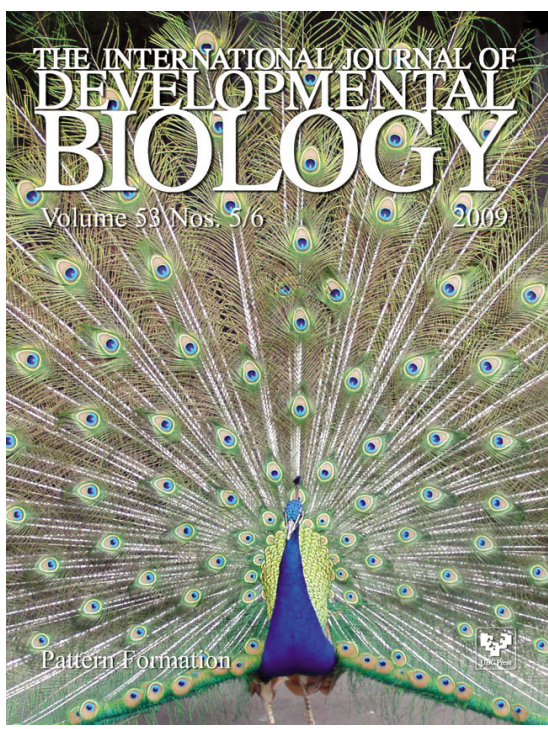
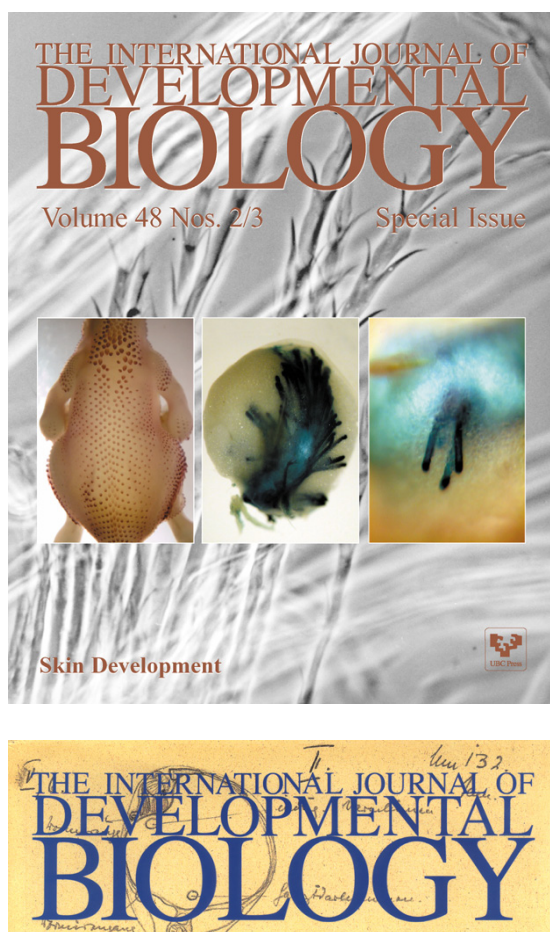

Volume 45 No. 1

Special issue
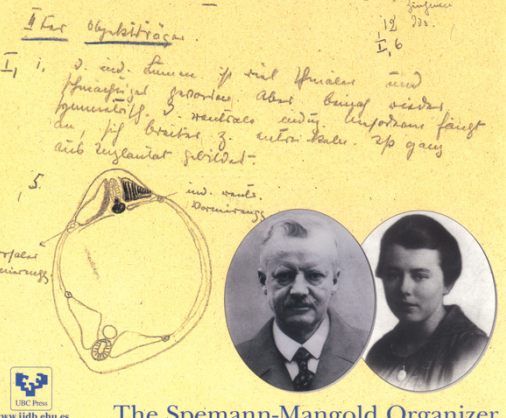

The Spemann-Mangold Organizer 